\title{
How to Reduce The Number of Domestic Violence Through Capacity Building of Organization
}

\author{
$1^{\text {st }}$ Maya Puspita Dewi ${ }^{1}, 2^{\text {nd }}$ Indah Wahyu Maesarini ${ }^{2}, 3^{\text {rd }}$ Anita Maulina ${ }^{3}$ \\ \{maya.pd@stiami.ac.id ${ }^{1}$ \} \\ Institut Ilmu Sosial dan Manajemen Stiami ${ }^{1,2,3}$
}

\begin{abstract}
The issue of domestic violence is a serious social problem. Statistically the number of violence has escalated from year to year. In Indonesia the existence of an organization called the Integrated Services Center for Women and Children (P2TP2A) to support the elimination of domestic violence has not yet had a significant impact. The purpose of this study is to analyze the capacity building of organizational in an effort to reduce the number of domestic violence in Depok, West Java, Indonesia. This study used a qualitative case study method to describe the lack of capacity building of P2TP2A. The results of the study indicate that the high level of domestic violence is indeed caused by a lack of organizational capacity to respond to cases that occur. Hence, capacity building of organization can be a solution to reduce the number of domestic violence.
\end{abstract}

Keywords: Capacity Building, Organization, Domestic Violence.

\section{Introduction}

The issue of domestic violence has become a serious public issue, but still lacks an adequate response, both from the government, law enforcement officials, and the community at large. One reason is because fundamentally domestic violence is understood only as a matter of a domestic and personal nature. This case of violence is an iceberg phenomenon where actually reported cases are far less than cases that occur in the field (Ellsberg, 2006; Ortiz-Barreda, Vives-Cases, \& Gil-González, 2011). The presence of Non Government Organizations (NGOs) as a form of support for efforts to eliminate domestic violence is very necessary (Ellsberg, 2006).

In their study (Gibbs, Hardison Walters, Lutnick, Miller, \& Kluckman, 2015) evaluated several NGOs concerned with handling victims of human trafficking and sexual exploitation. The findings in the study were that there were obstacles from NGOs in providing services due to limited resources, and the absence of long-term programs to ensure the survival of the victims. Even though the victim / client really needs physical and mental protection.

Furthermore Duren Banks et.al. conducted a study of collaborative effort between child welfare agencies and domestic violence service providers who have the character "grass roots". The findings of the study were that there were improvements in the provision of advocacy and handling cases of violence against victims who were adults. But it depends on a more specific approach that is carried out by each community. In this case a more optimal collaboration strategy is needed (Banks, Hazen, Coben, Wang, \& Griffith, 2009).

Chaskin, (2000) in his study highlighted efforts to build community capacity in urban neighborhoods that focused on several strategies. The findings in the study were that there 
were obstacles in collaboration between community organizations that involved actors extensively in the process. Chaskin suggests several possible steps to build community capacity through several social changes.

In Indonesia, with the enactment of Law No. 23 of 2004 concerning the elimination of domestic violence has changed the problem domain which initially was in the private area, becoming a public area. The role of the community seems to be more active and responsive as evidenced by the establishment of a number of organizations at the central to the regional level who are concerned about the issue of domestic violence.

However, the existence of these organizations has not been able to reduce the number of domestic violence that is still high. On the other hand, it can also be interpreted as having more complex causes, so that the existence of these organizations is still too small compared to the magnitude of cases of violence that occurred (Bappenas, Australian Government, 2017). With the characteristics of volunteer-based that working at the grassroots level, the organization is actually considered to better understand the problems of the community (Lukaszczyk \& Williamson, 2010). Hence, the capacity building of organization to carry out its functions effectively and efficiently is a problem in itself.

\section{Method}

This study used a qualitative case study method to analyze the capacity building of P2TP2A in Depok City, West Java, Indonesia. This method was chosen because of its function to describe, approve, and assist information (Seidman, 2006). The information collected is used as a basis for analyzing the phenomena that occur. The reason for choosing this model is because of case studies study of phenomena in the real world context (Yin, 2009). Case study research depends on various sources according to the data needed. The study was conducted through observations, interviews and study of related documents. Observations were carried out in P2TP2A Depok City regarding all activities related to efforts to deal with domestic violence. In-depth interviews conducted with stakeholders concerned to explore the depth of the problem, lasting approximately 40 minutes for each informant. Documentation studies are carried out by examining related documents to provide additional information. The case study lasted for 3 months in 2018. A total of seven informants consisting of two staffs of the organization, one officer of the Depok City Social Service, two volunteers, and two victims of domestic violence were selected purposively. Data analysis was carried out through three stages, namely reducing data, presenting data, and drawing conclusions / verification (Matthew B.Miles, A. Michael Huberman, 2013).

\section{Result and Discussion}

Much research has been conducted on the capacity building of organizational. Millar \& Doherty (2016) studied the comprehensive model of developing capacity and relationships in it; Cairns, Harris, \& Young (2005) analyzed the challenges for organizations to increase capacity while maintaining organizational distinctiveness and independence; (Irawan, 2016) who studied aspects of organizational development in responding to social services for homeless children.. Almost the same study was conducted by (Chaskin, 2000; Clark \& Petts, 1999; Harrow, 2010; Kaplan, 2000; M.Shahul Hameedu, 2014; Scottish Community 
Development Centre, 2007; Twigg, 2001; Wing, 2004). The present research aims to analyze the capacity building of P2TP2A in an effort to reduce the number of domestic violence by focusing on human resource development, organizational strengthening and institutional reform.

The form and structure of P2TP2A is more a supplement and not a substitution from an institution that already exists in the government. The activities of this organization focus on 'informal' coordination and supervision efforts with relevant government institutions that have the task and function of empowerment (Bappenas, Australian Government, 2017). This organization is created by the government, but have characteristics such as NGOs, volunteerbased, who are exist to pay attention to more specific issues (M.Shahul Hameedu, 2014).

The National Committee on Violence Against Women in Indonesia has issued data on the following number of domestic violence reported on a national scale:

Chart 1

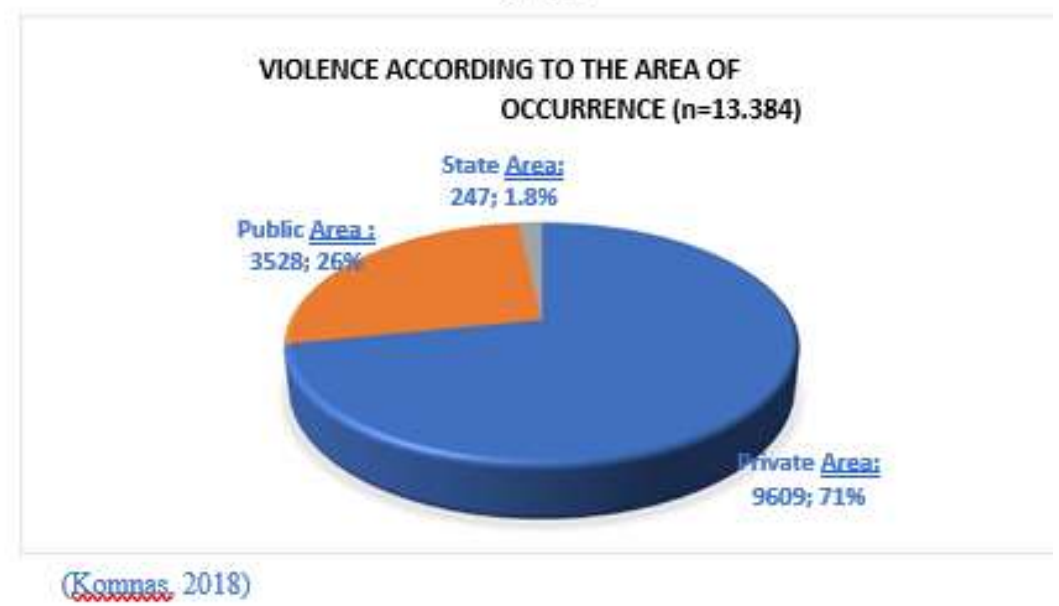

Chart 2

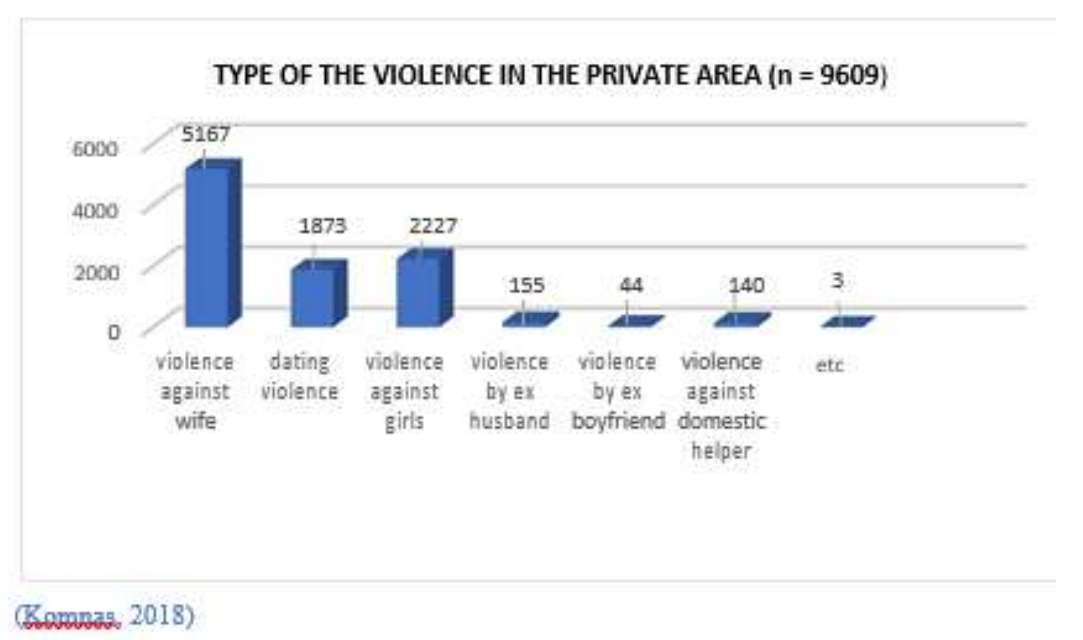


In Depok City, based on the reports from P2TP2A regarding the number of violence known as follows:

Table 1.Recapitulation cases of violence handled by P2TP2A $2014-2017$

\begin{tabular}{|c|c|c|c|c|}
\hline Type of case & $\mathbf{2 0 1 4}$ & $\mathbf{2 0 1 5}$ & $\mathbf{2 0 1 6}$ & $\mathbf{2 0 1 7}$ \\
\hline Physical abuse & 1 & 2 & 5 & 7 \\
\hline Psychological violence & - & 1 & 3 & 3 \\
\hline Sexual violence & 19 & 13 & 25 & 43 \\
\hline Exploitation & - & 2 & 2 & 2 \\
\hline Child custody & - & 2 & 5 & 6 \\
\hline Domestic violence & 24 & 14 & 10 & 16 \\
\hline Traficking & 1 & 1 & 2 & 1 \\
\hline anothers & - & - & - & 5 \\
\hline
\end{tabular}

Source: P2TP2A; 2014-2017.

The data above shows, that the number of violence in the private area is still very high. Violence against wife is in the highest position, then followed by violence against girls on the second position. This means that even in the most private area, in a family, a wife and a daughter are still unsafe. Based on the result obtained during research, many factors caused this to occur, including due to the lack of capacity building of P2TP2A. The lack of professional human resources, budget issues, infrastructure and weak leadership and managerial factors make the performance of this organization not optimal in reducing the number of domestic violence. McKinsey \& Company (2001) said that the key to the success of capacity building of an organization depends on the management process and the strength of the influence of organizational leadership. This is believed to be the key that can spur organization acceleration in carrying out its role.

In terms of regulation there is actually no serious problem regarding the existence of this organization even though it is considered to be structurally ambiguous and lacking in authority. The role and function played by this organization is considered unique and is a breakthrough from the institutional structure model in the government. The problems that arise actually come from the existing system in the organization, which shows that the capacity building of organization is still far from ideal conditions. As said that organizational capacity development is intended so that the organization can respond to changes in the surrounding environment and make the organization stronger (Dewi, Rahmatunnisa, Sumaryana, \& Kristiadi, 2018) in order to be able to implement government policies and bring about the transformation of very important values in society (Besler \& Sezerel, 2011).

As Wing (2004) said in order to develop the capacity of an organization must have a sufficient number of staff who have the necessary knowledge and skills, appropriate and adequate technical and management systems, appropriate remodeling of infrastructure, and adequate financial resources. Furthermore, Hilderbrand \& Grindle (1997) said that the capacity building of an organization must focus on the dimensions of human resources development, dimensions of organizational strengthening and institutional reform. 


\section{Conclusion}

Based on the discussion above, the capacity building of P2TP2A is still far from ideal conditions. Lack of professional human resources, budget problems, lack of adequate infrastructure, managerial that still needs to be improved, are the causes of the ineffective role played by P2TP2A to reduce the number of domestic violence. Hence, P2TP2A needs to develop its organizational capacity immediately by focusing on developing human resources, strengthening organizations and institutional reform. The big role of P2TP2A cannot be realized without building its capacity,

\section{Acknowledgement}

Many thanks to Institut Ilmu Sosial dan Manajemen Stiami for providing full funding in this research. Thank you also to the Dean of the Faculty of Administrative Sciences Institut Ilmu Sosial dan Manajemen Stiami and Head of the Study Program who have given endless support. Then I thank to Lembaga Penelitian dan Pengabdian Masyarakat Institut Ilmu Sosial dan Manajemen Stiami which has facilitated and assisted this research. Hopefully this research can contribute to the development of Public Administration, especially regarding the issue of capacity building of organizations.

\section{References}

[1]. Banks, D., Hazen, A. L., Coben, J. H., Wang, K., \& Griffith, J. D. (2009). Collaboration between child welfare agencies and domestic violence service providers: Relationship with child welfare policies and practices for addressing domestic violence. Children and Youth Services Review, 31(5), 497- 505. https://doi.org/10.1016/j.childyouth.2008.10.005

[2]. Bappenas, Australian Government, K. P. (2017). Membangun Akses ke Keadilan bagi Perempuan Korban Kekerasan : Jakarta.

[3]. Besler, S., \& Sezerel, H. (2011). Core competences in non-governmental organizations: A case study. Procedia - Social and Behavioral Sciences, 24, 1257-1273. https://doi.org/10.1016/j.sbspro.2011.09.106

[4]. Cairns, B., Harris, M., \& Young, P. (2005). Building the Capacity of the Voluntary Nonprofit Sector: Challenges of Theory and Practice. International Journal of Public Administration, 28(9-10), 869-885. https://doi.org/10.1081/PAD-200067377

[5]. Chaskin, R. J. (2000). Building community capacity: A definitional framework and case studies from a comprehensive community initiative. Urban Affairs Review, 36(3), 291-323. https://doi.org/10.1177/10780870122184876

[6]. Clark, B. D., \& Petts. (1999). "Capacity building," 35.

[7]. Dewi, M. P., Rahmatunnisa, M., Sumaryana, A., \& Kristiadi, J. B. (2018). Ensuring Service Quality in Education for Indonesia's Sustainable Education. Journal of Social Studies Education Research Sosyal, 9(4), 65-81. https://doi.org/10.17499/jsser.26856

[8]. Ellsberg, M. (2006). Violence against women and the Millennium Development Goals: Facilitating women's access to support. International Journal of Gynecology and Obstetrics, 94(3), 325-332. https://doi.org/10.1016/j.ijgo.2006.04.021

[9]. Gibbs, D. A., Hardison Walters, J. L., Lutnick, A., Miller, S., \& Kluckman, M. (2015). Services to domestic minor victims of sex trafficking: Opportunities for engagement and support. Children and Youth Services Review, 54, 1-7. https://doi.org/10.1016/j.childyouth.2015.04.003

[10]. Harrow, J. (2010). "Capacity building" as a public management goal: Myth, magic or the main chance? Public Management Review, 3(2), 209-230. https://doi.org/10.1080/14616670010029593 
[11]. Hilderbrand, M. E., \& Grindle, M. S. (1997). Getting good government: capacity building in the public sectors of developing countries. (p. 504). Harvard Institute for International Development, Harvard University. https://doi.org/doi:10.1016/S0022-1694(99)00120-1

[12]. Irawan, B. (2016). Organizational capacity development to respond to social services for homeless children. Indian Journal of Science and Technology, 9(39). https://doi.org/10.17485/ijst/2016/v9i39/93184

[13]. Kaplan, A. (2000). Development in Practice Capacity building: Shifting the paradigms of practice. Development in Practice, 10(3-4), 517-526. https://doi.org/10.1080/09614520050116677

[14]. Komnas, P. (2018). Tergerusnya Ruang Aman Perempuan Dalam Pusaran Politik Populisme. Jakarta.

[15]. Lukaszczyk, A., \& Williamson, R. (2010). The role of space related non-governmental organizations (NGOs) in capacity building. Advances in Space Research, 45(3), 468-472. https://doi.org/10.1016/j.asr.2009.10.004

[16]. M.Shahul Hameedu, R. S. K. (2014). Changing scenario of capacity building. International Journal of Current Research and Academic Review, 2(1), 46-57.

[17]. Matthew B.Miles, A. Michael Huberman, J. S. (2013). Qualitative Data Analysis (3rd editio). USA: SAGE Publications, Inc.

[18]. McKinsey \& Company. (2001). Effective Capacity Building in Non-profits. Venture Philanthropy Partners.

[19]. Millar, P., \& Doherty, A. (2016). Capacity building in nonprofit sport organizations: Development of a process model. Sport Management Review, 19(4), 365-377. https://doi.org/10.1016/j.smr.2016.01.002

[20]. Ortiz-Barreda, G., Vives-Cases, C., \& Gil-González, D. (2011). Worldwide violence against women legislation: An equity approach. Health Policy, 100(2-3), 125-133. https://doi.org/10.1016/j.healthpol.2010.11.015

[21]. Scottish Community Development Centre. (2007). Building Community Capacity Resources for Community Learning \& Development Practice A Guide Complied by the Scottish Community Development Centre for Learning Connections.

[22]. Seidman, I. (2006). Interviewing_As_Qualitative_Research (third edit). New York: Teacher College Press. https://doi.org/10.1037/032390

[23]. Twigg, J. (2001). Capacity Building And Its Challenges A Review Of The Baring Foundation's International Grants Programme 1997-99, 5(December).

[24]. Wing, K. T. (2004). Assessing the Effectiveness of Capacity-Building Initiatives: Seven Issues for the

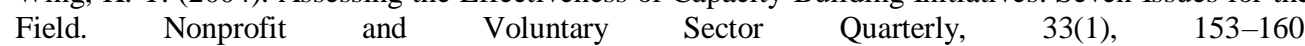
https://doi.org/10.1177/0899764003261518

[25]. Yin, R. K. (2009). Case Study Research; Design and Methods (Fourth Edi). USA: SAGE Publications. 